\title{
Studies on Metabolism of Parathion in Parathoin Susceptible and Resistant Larvae of the Rice Stem Borer ${ }^{1}$
}

\author{
By Ken'ichi Kojima, Tadayoshi Ishizuka, Akio Shino and Setsuo KitaKata \\ Institute of Agricultural Chemicals, Toa Noyaku Co. Ltd., Odawara, Kanagawa, Japan
}

\section{INTRODUCTION}

It is well known that a number of organophosphorus insecticides and chlorinated hydrocarbon compounds are metabolized by insects, and the type of metabolic pathways depends on the chemical structure of compounds and species of insects. For example, DDT is metabolized by some species of insects and the metabolism follows at least five different pathways (Perry, 1960a, b). According to recent studies on insect resistance to organophosphorus insecticides, it is apparent that the resistance has an intimate relation with detoxication mechanism (BROwN, 1960 ; MARCH, 1959, 1960).

In Japan, parathion was tested at first on the pests of rice plants in 1951. It has shown excellent control against several species of rice pests, especially against larvae of the rice stem borer, Chilo suppressalis WALKer. So it has been widely used by rice growers since 1953 . However, in summer of 1960 , some rice growers at Zentsuji district of Kagawa Prefecture, in Western part of Japan, complained about the much lowered effect on larvae of rice stem borer. As a result, the area was inspected. And the authorities of Kagawa Prefecture reported that several other insecticides such as methyl parathion, EPN, dipterex and BHC were still effective on the larvae of rice stem borer in that district. Therefore, the situation looked that there were no failures in the spray timing, the application methods, and the amount of active ingredients used, but rather the rice stem borer built some resistance to parathion.

According to our preliminary test, parathion resistant larvae in Kagawa (collected from rice field of Zentsuji and Sakaide Cities, Kagawa Prefecture; hereafter abbreviated $\mathrm{R}$ ) showed over twice resistance in the first brood and over 5 times resistance in the second brood to parathion, in the $L_{50}$ value by the topical application or in the $\mathrm{LC}_{50}$ value by the spray method on pot, as compared with parathion susceptible larvae in Shizuoka (collected from rice fields of Shizuoka City, Shizuoka Prefecture; hereafter abbreviated S). The $\mathrm{R}$ larvae were also resistant to paraoxon, but there was no significant differences in susceptibility to parathion and paraoxon between $S$ and $R$ larvae in diapausing stage, because the resistant factors to parathion and paraoxon in the $R$ larvae were not retained during diapause.

As shown Table 1, it is apparent that $\mathrm{R}$ larvae degraded paraoxon more rapidly than S larvae in vivo by enzyme assay using human plasma cholinesterase and in vitro by Warburg manometric determination. But there was no differences between $S$ and $R$ in (1) the penetration of parathion or paraoxon through culticle, (2) the oxidation of parathion to paraoxon, (3) the activities of cholinesterase, Aesterase (aromatic- or aryl-esterase) and B-esterase (aliphatic- or ali-esterase), (4) sensibilities of above three enzymes to paraoxon (Kojima et al., unpublished data).

The present paper gives furthur informations on the metabolic detoxication mechanism of parathion by $R$ larvae as well as $S$ larvae of rice stem borer ap-

1 Studies on detoxication of insecticides, Part IX.

(Received for publication, December 8, 1962) 
Table 1. Physiological and biochemical aspect of insect resistance to organophosphorus insecticides

\begin{tabular}{|c|c|c|}
\hline Factor & $\begin{array}{l}\text { House } \\
\text { fly* }\end{array}$ & $\begin{array}{c}\text { Rice } \\
\text { stem } \\
\text { borer** }\end{array}$ \\
\hline $\begin{array}{l}\text { Penetration of insecticide } \\
\text { through the cuticle }\end{array}$ & - & - \\
\hline $\begin{array}{c}\text { Enzyme activity } \\
\text { Cholinesterase } \\
\text { A-esterase } \\
\text { B-esterase }\end{array}$ & $\begin{array}{l}- \\
\pm\end{array}$ & $\begin{array}{l}- \\
-\end{array}$ \\
\hline $\begin{array}{l}\text { Sensitivity to inhibitor } \\
\text { of enzymes } \\
\text { Cholinesterase } \\
\text { A-esterase } \\
\text { B-esterase }\end{array}$ & - & $\begin{array}{l}- \\
-\end{array}$ \\
\hline Activation & - & - \\
\hline Detoxication & + & + \\
\hline
\end{tabular}

- No significant difference.

\pm Lower activity in resistant strain than susceptible strain.

+ Higher activity in resistant strain than susceptible strain.

* Data published by March (1959).

** Our unpublished data.

plied with parathion topically.

\section{EXPERIMENTAL}

Insect: The experiment materials in diapausing and developing stages were obtained by the following way. Diapausing larvae were collected from rice straws which were reaped in Zentsuji City and Shizuoka City in December, 1960 respectively, and these larvae were kept in a laboratory without being exposed to any insecticides. We obtained continuously the developing larvae of the next generation.

Insecticide: Parathion was purified by a elution column chromatography using ether as a solvent.

Treatment, Extraction and Analysis: The larvae were treated topically with $1 \mu 1$ of $0.1 \%$ acetone solution of parathion on dorsal surface with a "Agla" micrometer syringe attached to a capillary tube. In this experiment, sex discrimination was neglected. After the treatment, ten treated larvae were kept in a petri dish under the room temperature of $25^{\circ} \mathrm{C}$ and $50 \%$ relative humidity without feeding. About one thousand larvae were used from each of $S$ and $R$ larvae. Mortality was observed at 5 or 24 hours after the treatment, and then larvae were homogenated in a mortar with $300 \mathrm{ml}$ of acetone. The homogenate was filtered and acetone layer was separated. After acetone was evaporated to dryness on a steam bath, it was partitioned with a mixiture of $100 \mathrm{ml}$ of $n$-hexane and $100 \mathrm{ml}$ of water. $n$-Hexane was discarded, and aqueous layer was partitioned with $30 \mathrm{ml}$ of chloroform, and then aqueous layer was separated by centrifigation and was subjected to the following ion exchange chromatography.

Ion exchange chromatography technics were used according to the method described by PlAPP and CASIDA (1958a). Ion exchange resin was Dowex 1-X8 (100200 mesh, $\mathrm{Cl}$ type). The eluting solvents were as follows :

I. $\mathrm{pH} 2$ to $\mathrm{pH} 1 \mathrm{HCl}$.

II. $\mathrm{pH} 1 \mathrm{HCl}$ plus methanol $(1: 3)$ to $1 \mathrm{~N}-\mathrm{HCl}$ plus methanol $(1: 3)$

III. $1 \mathrm{~N}-\mathrm{HCl}$ puls methanol $(1: 3)$ to concentrated $\mathrm{HCl}$, water, and methanol $(1: 1: 6)$.

Fractions $(10 \mathrm{ml})$ were collected at an interval of about 3.5 minutes. The aliquots $(1-5 \mathrm{ml})$ were analyzed for total phosphorus by Allen's method modified by Nakamura (1950).

Components contained in each fraction were identified by chromatography comparing with chromatograph of known samples. Known samples were obtained as follows: Parathion and paraoxon were hydrolyzed with alcoholic potassium hydroxide (PlapP and CASIDA, 1958b, c), and chromatographed by ion exchange column chromatography and then extracted from the elute with amyl alcohol or chloroform (Plapp and CASIDA, 1958a), and identified by infrared absorption spectra. The elution chromatograms and infrared spectra of the authentic samples are given in Figs. 1 and 2. 


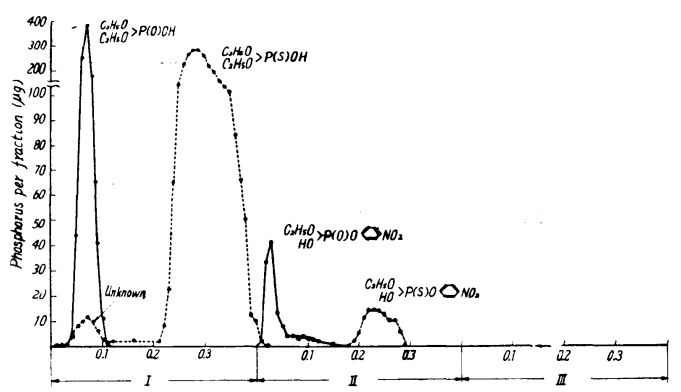

Fig. 1. Ion exchange separation on Dowex 1 of the derivatives of parathion and paraoxon. Solvent systems I, II and III are described in the text in detail.

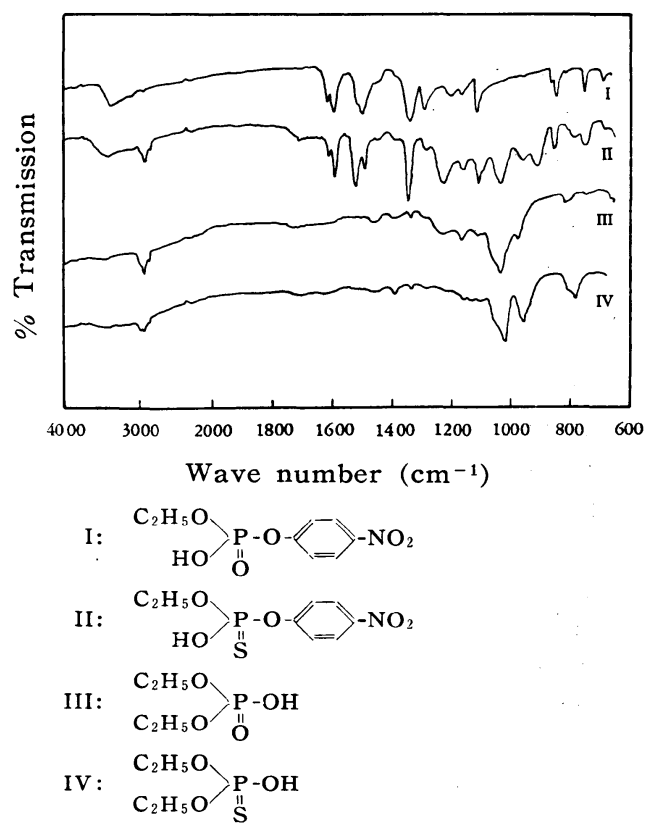

Fig. 2. Infrared spectra.

\section{RESULTS AND DISCUSSION}

Table 2 shows the results of the water soluble metabolites of $S$ and $R$ larvae of the rice stem borer applied with parathion topically.

As shown in Table 2, $O, O$-diethyl phosphorothioic acid, $O, O$-diethyl phosphoric acid, des-ethyl parathion, des-ethyl paraoxon and monomethyl phosphoric acid (or phosphoric acid) were found in both $\mathrm{S}$ and $\mathrm{R}$ larvae, but there were differences in quantities of each metabolite.
In both diapausing and developing stages, approximately same amount of des-ethyl parathion, $O, O$-diethyl phosphorothioic acid and monoethyl phosphoric acid (or phosphoric acid) were found. However, $O, O$-diethyl phosphoric acid was the predominant metabolite in the S larvae while des-ethyl paraoxon was predominant in the $\mathrm{R}$ larvae. The percentage of hydrolytic metabolite formed by cleavage of the aryl-phosphate bond of paraoxon showed no difference between the diapausing and developing stages among the $S$ and $R$ larvae, but alkyl-phosphate hydrolysis tends to increase in developing stage rather than diapausing stage, that is, the quantity of des-ethyl paraoxon was elevated from $25 \%$ in 24 hours to $41 \%$ in 5 hours in the $\mathrm{S}$ larvae and from $58 \%$ to $77 \%$ in the $\mathrm{R}$ larvae.

Plapp and Casida (1958c) demonstrated that certain dialkyl aryl phosphorothioates such as parathion, methyl parathion, diazinon, Dow ET-57, chlorthion and dicapthon were hydrolyzed at the alkylphosphate and the aryl-phosphate bonds. According to the studies by several workers on the hydrolysis of compounds of the type having the general formula of (RO) ${ }_{2} \mathrm{P}(\mathrm{Y}) \mathrm{OX}(\mathrm{Y}=\mathrm{O}, \mathrm{S})$, the common $\mathrm{P}-\mathrm{O}-\mathrm{X}$ bond is cleaved by mammals, insects and plants. PlAPP and CASIDA (1958c) also suggested that the alkyl-phosphate hydrolysis in mammals seemed to be an alternate mechanism for detoxication when the toxicant can not be detoxified through hydrolysis at aryl-phosphate bond, and that the detoxication by the cleavage of alkyl-phosphate bond was of minor importance in insects as compared with mammals. Nevertheless, it is noted that the major metabolic detoxication process in the $\mathrm{R}$ larvae was primarily due to the cleavage of alkyl-phosphate bond of paraoxon.

As shown above, organophosphorus insecticides were generally metabolized rapidly by insects. However, a little information has been obtained about the enzymes which are responsible for the 
Table 2. Hydrolytic metabolites of the parathion susceptible and

\begin{tabular}{c|c|c|c|c|c}
\hline \multirow{2}{*}{ Stage } & Larvae & $\begin{array}{c}\text { Average } \\
\text { body weight } \\
(\mathrm{mg})\end{array}$ & $\begin{array}{c}\text { Number of } \\
\text { larvae used }\end{array}$ & $\begin{array}{c}\text { Dosage } \\
(\mu \mathrm{g} / \text { larva })\end{array}$ & $\begin{array}{c}\text { Mortality } \\
(\%)\end{array}$ \\
\hline Diapausing $^{\mathrm{a}}$ & $\begin{array}{l}\text { Susceptible } \\
\text { Resistant }\end{array}$ & $\begin{array}{c}84.9 \\
57.6\end{array}$ & $\begin{array}{c}1077 \\
934\end{array}$ & 1 & 37.7 \\
\hline Developing & $\begin{array}{c}\text { Susceptible } \\
\text { Resistant }\end{array}$ & 12.3 & 584 & 1 & 33.5 \\
\hline
\end{tabular}

a Results at 24 hours after treatment, tested in February, 1961.

b Results at 5 hours after treatment, tested in July, 1961.

metabolic detoxication. From the several studies in vivo, the metabolism of paraoxon in insects and mammals follows at least three different metabolic detoxication pathways, as shown in Fig. 3.

At present, the cleavage sites of almost of all organophosphorus compounds by enzymes in vitro have not been confirmed except for DFP by DFPase (MAZUR, 1946; Mounter and Dien, 1954), tabun by tabunase (Augustinsson and Heimbürger, 1954), and sarin by sarinase (Hoskin, 1956), in mammals. AldRidge (1953a, b) has reported an enzyme which hydrolyzes paraoxon to $O, O$-diethyl phosphoric acid and $p$-nitrophenol, in mammalian sera and other tissues. He concluded that paraoxonhydrolyzing enzyme in serum identical with A-esterase which was known to hydrolyze $p$-nitrophenyl acetate but not to be inhibited by paraoxon. Mounter and WhitTAKER (1953) also suggested that serum aryl-esterase was identical with paraoxonhydrolyzing A-esterase. Later, Mounter (1954) and Augustinsson (1953) confirmed the observation of AlDRIDGE (1953a, b) that one enzyme in mammalian sera hydrolyzed $p$-nitrophenyl acetate and paraoxon. And Mounter (1954) cleared that TEPP and DFP were also hydrolyzed by A-esterase. Recently, however, MAIN (1960a, b) purified an enzyme that hydrolyzed paraoxon in sheep serum, and he showed that paraoxon-hydrolyzing enzyme was different from A-esterase. Thus he called the enzyme paraoxonase to distinguish from other A-type-esterase. ERDös and BogGS (1961) also indicated that in addition to A-esterase, manmalian serum albumin hydrolyzed paraoxon at an appreciable rate.

On the other hand, Metcalf et al. (1956) presented that A-esterase in insect tissues hydrolyzed papaoxon and parathion, liberating $p$-nitrophenol. Contrary to the result of Metcalf et al., LORd and Solly (1956) reported that A-esterase preparation of house flies did not hydrolyzed paraoxon. KRUEGER and CASIDA (1961) demonstrated that the enzymes hydrolyzing dialkyl phosphoric anhydrides in house flies could be at least partially separated from the cholinesterase, A-esterase and B-esterase, and more than one esterase of the house fly acted on the phosphates. We found that the activities of cholinesterase, Aesterase and B-esterase in the larvae of the rice stem borer were not related to the hydrolyzing activity of paraoxon and parathion (Kojima et al., unpublished data).

Although the enzyme activity, which is responsible for cleavage of the alkylphosphate bond of paraoxon, is not demonstrated yet for any animals in vitro, the enzymatic hydrolysis of paraoxon by the $\mathrm{R}$ larvae which we observed manometrically is considered to be attributed to a new enzyme which cleaves alkyl-phosphate 
resistant larvae of the rice stem borer applied with parathion topically

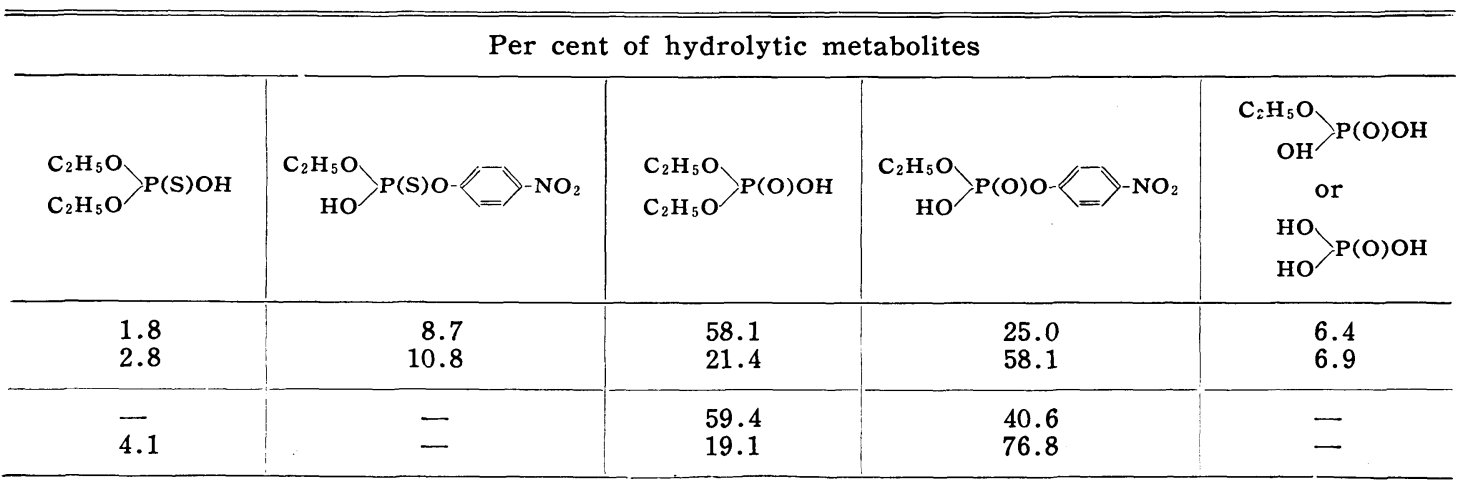

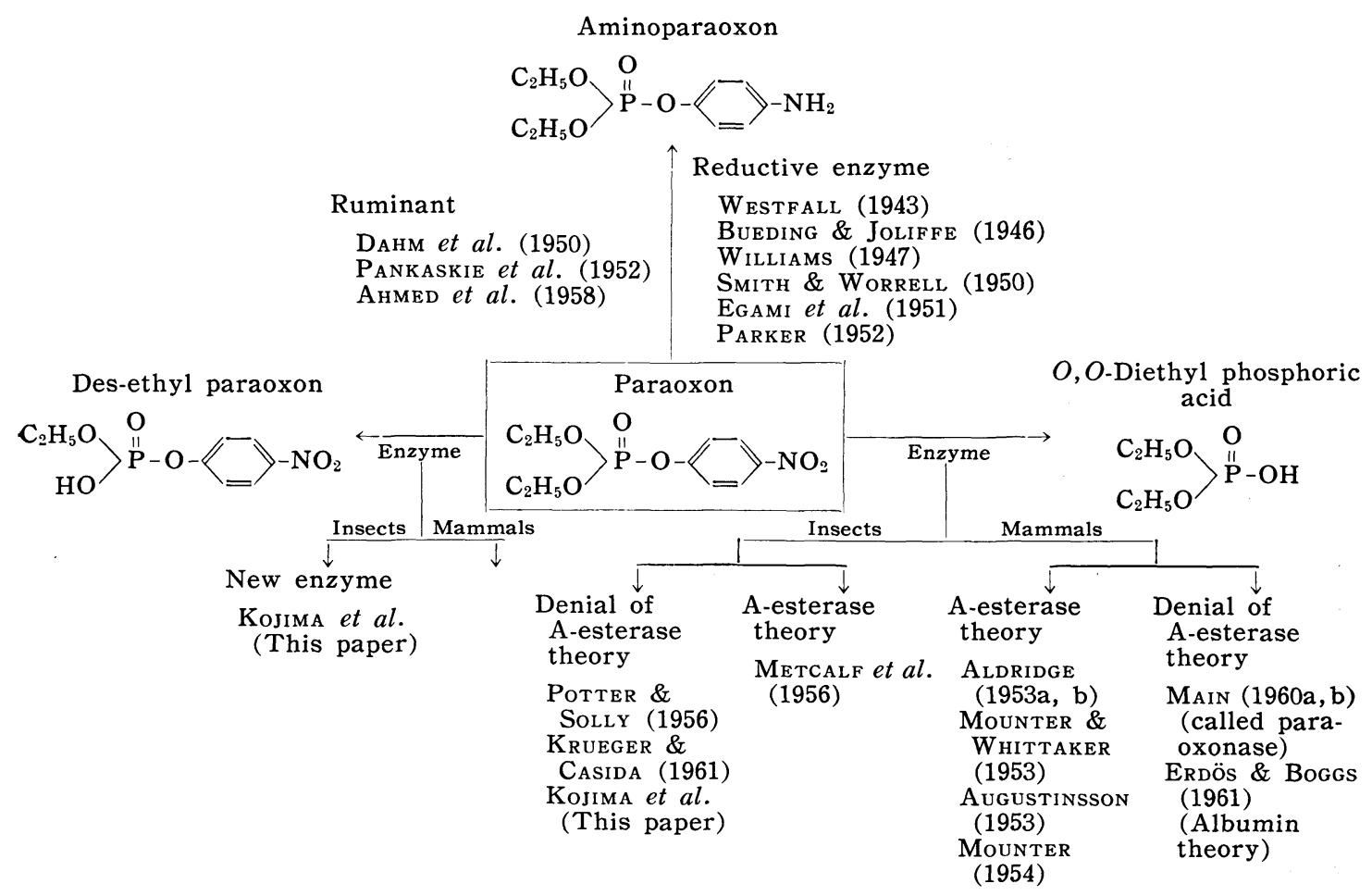

Fig. 3. Possible pathways and responsible enzymes in paraoxon metabolism of mammals and insects.

bond of paraoxon. We have been working on purification and characterization of the enzyme in the $S$ and $R$ larvae of rice stem borer. In case of the rice stem borer, it seems that the development of parathion resistance is originated in change of the enzyme responsible for the detoxica- tion of paraoxon. According to O'BRIEN's hypothesis (1959), in which "weak link" is presented as a responsible factor for the selective toxicity of organophosphorus insecticides, it seems that the alkyl-phosphate bond of paraoxon is related to the mechanism of parathion resistance in rice 
stem borer.

Moreover, in the ruminant, it has been reported that the reduction of parathion and paraoxon is a major metabolic detoxication pathway, by DАнм et al. (1950), Pankaskie et al. (1952) and Ahmed et al. (1958). On the other hand, it has been shown that the enzyme system which reduces aromatic nitro compounds to amino compounds exists in organisms, by Williams (1947), Bueding and Joliffe (1946), Westfall (1943), SMith and Worrell (1950), EGami et al. (1951) and PARKER (1952), but this reduction is prevented by cyanides (EGAMI et al., 1951 ; PARKER, 1952). However, it is not yet proved in vitro and in vivo whether this enzyme system is responsible for the reduction of parathion and paraoxon in animals.

\section{SUMMARY}

The mechanism of metabolic detoxication of parathion in the rice stem borer was examined in relation to parathion resistance.

From each of susceptible and resistant larvae, $O, O$-diethyl phosphorothioic acid, $O, O$-diethyl phosphoric acid, des-ethyl parathion, des-ethyl paraoxon and monoethyl phosphoric acid (or phosphoric acid) were detected, but there were differences in quantities of each metabolite. But there were almost equal amount of des-ethyl parathion, $O, O$-diethyl phosphorothioic acid and monoethyl phosphoric acid (or phosphoric acid) in the susceptible and resistant larvae. However, $O, O$-diethyl phosphoric acid was the predominant metabolite in the susceptible larvae while des-ethyl paraoxon was predominant in the resistant larvae. It seems that alkylphosphate bond of paraoxon is a "weak link" which is responsible for selective toxicity between parathion susceptible and resistant larvae of the rice stem borer.

\section{ACKNOWLEDGEMENT}

We wish to express our thanks to Profs. Ryo Yamamoto and Nobumasa Yagi, Tokyo Agricultural University, for their invalu- able advice and encouragement as well as for the constant guidance throughout this work. Also we wish to thank to Prof. Kisabu Iүатомі, Laboratory of Applied Entomology, Facilty of Agriculture, Nagoya University, and to Dr. Seiroku SAKAI, Institute of Agricultural Chemicals, Yashima Chemicals Industry Co. Ltd., and to Dr. Kozaburo Ozaki, Division of Entomology, National Institute of Agricultural Sciences, for their kind suggestions and discussions concerning this work. We are very grateful to Dr. Rokurō SAtō and Mr. Singo Gото̄, Ministry of Agriculture and Forestry, Agricultural Chemicals Inspection Station, for infrared spectra determination.

\section{REFERENCES}

Ahmed, M. K., J. E. Casida and R. E. Nichols (1958) J. Agr. Food Chem. 6: 740.

Aldridge, W. N. (1953a) Biochem. J. 53: 111.

Aldridge, W. N. (1953b) Biochem. J. 53: 117.

Augustinsson, K. B. (1953) Acta Pharmacol. Toxicol. 9: 245 .

Augustinsson, K. B. and G. Heimbürger (1954) Acta Chem. Scand. 8: 762.

Brown, A. W. A. (1960) Annu. Rev. Entomol. 5: 301.

Bueding, E. and N. Joliffe (1946) J. Pharmacol. 88: 300 .

Dahm, P. A., F. C. Fountaine, J. E. Pankaskie, R. C. Smith and F. W. Atkeson (1950) J. Dairy Sci. 33: 747.

Egami, F., M. Eвata and R. I. SAto (1951) Nature, London 167: 118.

Erdös, E. G. and L. E. Boggs (1961) Nature, London 190: 716 .

Hoskin, F. C. G. (1956) J. Biochem. Physiol. 34: 75.

KoJima, K., et al. Unpublished.

Krueger, H. R. and J. E. CAsida (1961) J. Econ. Entomol. 54: 239.

LoRD, K. A. and S. R. B. Solly (1956) Chem. \& Ind., London 1352.

MaIN, A. R. (1960a) Biochem. J. 75: 10.

MaIN, A. R. (1960b) Biochem. J. 75: 188.

March, R. B. (1959) Misc. Publ. Entomol. Soc. Am. 1: 13.

March, R. B. (1960) Misc. Publ. Entomol. Soc. Am. 2: 139.

Mazur, A. (1946) J. Biol. Chem. 164: 271.

Metcalf, R. L., M. Maxon, T. R. Fukuto and 
R. B. MARCH (1956) Ann. Entomol. Soc. Am. 49: 274 .

Mounter, L. A. (1954) J. Biol. Chem. 209: 813. Mounter, L. A. and L. T. H. Dien (1954) Proc. Soc. Extl. Biol. Med. 87: 40.

Mounter, L. A. and V. P. Whittaker (1953) Biochem. J. 54: 551.

Nakamura, M. (1950) J. Agr. Biol. Chem. Japan 24: 1 .

O'Brien, R. D. (1959) Canad. J. Biochem. Physiol. 37: 1113.

Pankaskie, J. E., F. C. Fountaine and P. A. Dahm (1952) J. Econ. Entomo1. 45: 51.
Parker, V. H. (1952) Biochem. J. 51: 363.

- Perry, A. S. (1960a) J..Agr. Food Chem. 8: 226. Perry, A. S. (1960b) Misc. Publ. Entomol. Soc. Am. 2: 119.

Plapp, F. W. and J. E. CASida (1958a) Analyt. Chem. 30: 1622.

Plapp, F. W. and J. E. Casida (1958b) J. Agr. Food Chem. 6: 662 .

Plapp, F. W. and J. E. CASIDA (1958c) J. Econ. Entomol. 51: 800 .

Westfall, B. B. (1943) J. Pharmacol. 78: 386.

Williams, R. T. (1947) Detoxication mechanism, London, Chapman and Hall.

\section{摘要 \\ パラチオン感受性打よび抵抗性ニカメイガ幼虫に打けるパラチオンの代謝}

小島建一・石塚忠克・椎野明雄・北方節夫

（東西農薬株式会社農薬研究所）

最近, MARCH や BROWN は有機燐殺虫剂に対して抵 抗性のイエバエの系統が有機塩素殺虫剂に対して抵抗性 のものと種々の点で著しく異なることを報告し, イエバ 工の有機燐殺虫棛感受性, 抵抗性の両系統のいずれの系 統においてもそのコリンエステラーゼ活性度やコリンエ ステラーゼ阻害剂に対する感受性には有意な差異がな く，また体内に打ける投与薬郕の活性化作用も両系統間 に差がないこと，そして抵抗性はむしろ解毒機構に関係 するところが大で，体内の作用点に有機燐郕が薬効発現 の臨界濃度に蓄積される速さに対し，その殺虫戍が体内 で分解されて無毒物質に変化する速さとの関倸が抵抗性 機構に大きく関与することを指摘した。

ところで, 有機燐殺虫戍抢よび有機塩素殺虫剂の代謝 的分解は薬剂の化学構造や生物の種類によって異なるこ
とが知られている。我々はニカメイガ幼虫によるパラチ オンの代謝を明らかにすると共に，パラチオンに対する 抵抗性と解毒機構との関係を解明するため, パラチオン 感受性および抵抗性二カメイガ幼虫にパラチオンを局所 施用し, その分解物をイオン交換樹脂クロマトグラフに よって分離した。その結果, 体内における分解解毒は感 受性および抵抗性幼虫共にパラオクソンで行われること がわかった。しかし，感受性幼虫ではパラオクソンの aryl-phosphate 結合の分解によって代謝されるが，抵 抗性幼虫は昆虫では重要な代謝経路でないといわれてい る alkyl-phosphate 結合の分解によって代謝されるこ とを示した。さらにパラオクソンの分解を触媒する醭素 について論じた。 